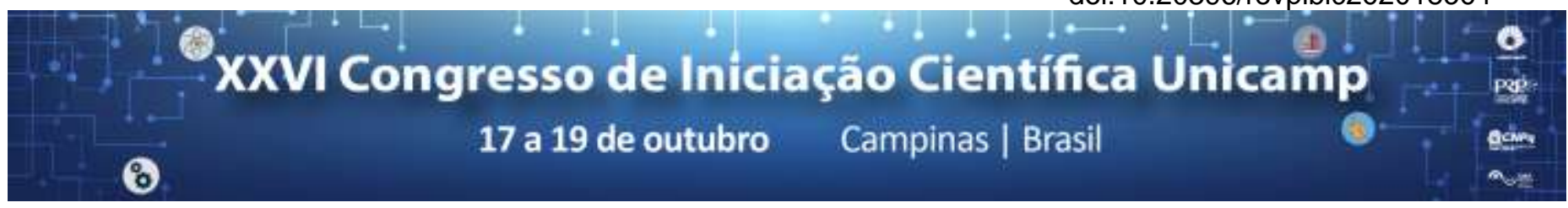

\title{
Aspectos da Estética Japonesa na obra de Vincent van Gogh
}

\section{Eder Aleixo, Taisa Helena Pascale Palhares}

\section{Resumo}

Dada uma aproximação existente entre o pensamento artístico de van Gogh e a arte japonesa, tendo suas obras e suas cartas como testemunho dessa relação, o projeto propôs movimentar as relação entre a estética japonesa e a sua forma com a produção do artista. A proposta é revisitar com um foco diferente uma produção já tão conhecida, selecionando vestígios que parecem não tem recebido a atenção necessária em razão de uma tradição do pensamento eurocêntrico na academia, e assim aprofundar as reflexões sobre o tema. As análises intentam discutir as relações entre conceito, forma e assimilação de conteúdo. Evidenciando a diferente formação cultural do pintor e as idiossincrasias referente a maneira como teve acesso às informações sobre a arte japonesa.

Palavras-chave: Van Gogh, Ukiyo-e, Estética.

\section{Introdução}

Van Gogh possui diversas referencias artísticas, como a escola de Barbizon e os Impressionistas, e o impacto desses referenciais em sua produção é constante discutido na academia. Dentre esses referenciais encontra-se a arte japonesa do Ukiyo-e, da qual o artista possuía uma coleção com mais de quinhentos exemplares (coleção disponível no museu van Gogh de Amsterdam). O trabalho visou a análise da obra do artista segundo seu conhecimento da arte Japonesa e o impacto descrito por ele em suas cartas uma vez que o artista declara "que em certa medida toda sua obra é baseada na arte japonesa" ${ }^{1}$. As discussões são guiadas pelos relatos do artista em suas cartas, por seus biógrafos e pelo estudo da estética japonesa relacionada ao ukiyo-e. O intuito é de popularizar e ressaltar a importância do modelo japonês para a obra de van Gogh uma vez que a academia parece tratar tal referência como menor. $E$ também entender a como e o quanto $\mathrm{o}$ artista se aproximou das bases conceituais e formais da arte japonesa.

\section{Resultados e Discussão}

Van Gogh usa sua coleção de gravuras japonesa (ex. Figura 1) para construir sua maneira de representar. Das gravuras ukiyo-e ele assimila relações de harmonia no uso de cores complementares e formas de pensar o espaço compositivo. O artista inclusive realiza copias dos Ukiyo-e que possuía, como método de assimilação dos vocabulários visuais que compõe o modelo.

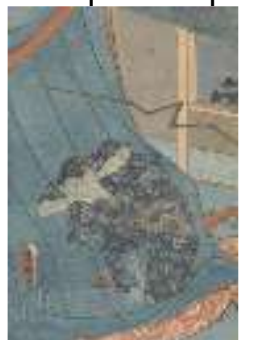

Figura 1. Mulher escondendo-se sob a tela para mosquitos folha esquerda do tríptico: Chuva repentina de verão - Utagawa Kunisada, 1852-52 xilogravura, $37 \times 26 \mathrm{~cm}-$ Museu van Gogh

Em suas cartas o Artista faz diversas referências a arte japonesa, e a importância do modelo para a arte de sua época e trata os mestre do ukiyo-e como autoridades artísticas incontestáveis, que permitiam a ele realizar investigações fora da retórica visual europeia.

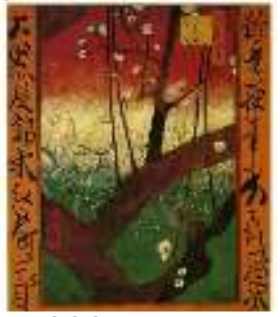

Figura 2. VINCENT VAN GOGH: Japonaiserie: Ameixeira em Flor (segundo Hiroshige). 1887. Oleo sobre tela, 55 x $46 \mathrm{~cm}$.

O ukiyo-e é embebido em diversos conceitos estéticos da tradição japonesa, sendo que iki, suki $e$ furiyuu os principais representados dentro da coleção possuída pelo artista, são eles responsáveis pela forma que atraiu van Gogh e que foi repetida pelo artista. E guardada as devidas proporções esses conceitos também estão representados em obra como a Figura 3.

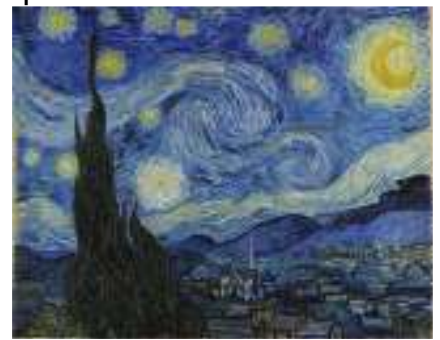

Figura 3. noite estrelada - vincent van Gogh, 1888 - oleo sobre tela, $73 \times 92$ $\mathrm{cm}-\mathrm{MOMA}$

\section{Conclusões}

A forma da obra de arte japonesa é representação de seus códigos estéticos. Através do estudo dessa forma o artista foi capaz de reproduzir em sua própria produção o mesmo tipo de intenção que é despertada por iki, suki e furyuu, mesmo sem conhecimento especifico a respeito dos mesmos. É graficamente que ele representa o ideal posto na arte japonesa.

\section{Agradecimentos}

Agradeço a FAPESP por apoiar e financiar a pesquisa, e a minha orientadora Taísa Helena Pascale Palhares que aceitou me orientar quando nenhum outro professor se interessou pelo tema.

\footnotetext{
1 Vincent van Gogh, carta 620, vangoghletters.org, 1888.
} 